\title{
To Evaluate the Effectiveness of Planned Teaching on Knowledge Regarding Hypnobirthing Among Primigravida Women
}

\author{
Kavita Gomase, Sonali Katkar, Vaishali Khaire, Akshata Khawashi, Nikita \\ Khekare, Shital Khobragde, Lalremkimi and Asmita Lamsonge \\ Department of Obstetrics and Gynaecology Nursing, SRMM College of Nursing Datta Meghe Institute of Medical \\ Sciences, (Deemed to be University), Sawangi Meghe, Wardha, Maharashtra, India
}

\section{ABSTRACT}

Labor and birth hypnotherapy is focused on the idea that a woman's fear and stress of labor and birth contributes to muscle discomfort and eventually increased pain that contributes to more fear and stress continuing the cycle (PhillipsMoore, 2012) by using hypotherapy to teach a woman how to interact with the natural process of her body. The aim of this study was to assess the effectiveness of planned teaching on hypnobirthing awareness among primigravida women. This research included a total of 100 women with primigravida. It has been adopted pre experimental one group pretest post-test research design. The tool's material validity was carried out by different experts from various fields. Suggestions proposed were incorporated in tool and appropriate change were made. Reliability analysis was done by intra class correlation. Structured teaching program followed data collection within 15 days by group members pre-test data collection. The data were analyzed using different stastic tests including percentage, mean and standard deviation. The student t-test and chi-square test carried out the study. The $\mathrm{p}<0.05$ has been regarded as statistically important. The result shows that 3 percent of primigravida women in pretest had poor knowledge score, average 61 percent in pretest, good 34 percent in pretest, very good 2 percent in pretest and very good knowledge score at 100 percent posttest. Minimum knowledge score was 4 in pretest and 7 in posttest, maximum knowledge score was 16 in pretest and 20 in posttest. The mean pretest information score was 9.77(2.44) and $17.66(2.18)$ in the post exam. The results suggested the impact of the proposed teaching program on overall awareness of primigravida female hypnobirthing.

\section{KEY WORDS: PRE-LABOUR TECHNIQUES, THE RELAXATION EXERCISES.}

\section{INTRODUCTION}

Hypnobirth helps you to observe birth in an environment of peace, comfort, free from anxiety and stress that prevents the body's birth muscles from working as they were conceived by nature in 1990 by Marie. F.Mongan. Hypnobirthing is a full system of birth education, which helps to monitor their wives and give them a better understanding of conception. This includes teaching basic and complex methods of self-hypnosis, calming, and breathing. Any single set of values is hypnobirthing.

Biosc Biotech Res Comm P-ISSN: 0974-6455 E-ISSN: 2321-4007

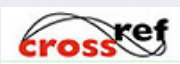

Identifiers and Pagination

Year: 2021 Vol: 14 No (9) Special Issue

Pages: $70-73$

This is an open access article under Creative

Commons License Attribn 4.0 Intl (CC-BY). DOI: $h t t p: / / d x$.doi.org/10.21786/bbrc/14.9.16
According to Andrew MI Medical play an important role in preserving lives and comfort they have become increasingly routine in normal childbirth. This may increase the risk of associated complication and a less satisfactory birth experience.

Hypnobirthing is described as a strategy for managing pain and anxiety during childbirth involving various techniques of therapeutic relaxation, such as deep breathing and visualization. The best time to start classes in Hypnobirthing course is between 25 weeks and 29 weeks of pregnancy, but you may benefit from the classes right up to the end of your pregnancy. The calming exercises are best performed with the father or birth partner so that the sound of his or her voice or touch is an instant source for relief as the mother goes into labour Both methods of meditation and visualization are performed in the weeks leading up to birth, alongside essential exercise of relaxation accompanied by scripts, help to
Article Information

Received: $19^{\text {th }}$ Apr 2021 ccepted after revision: $24^{\text {th }}$ June 2021 
alleviate anxiety. Some of the most critical aspects of a hypnobirthing course is the task of calming anxiety and building trust like everything else, the more expectant mothers practice relaxation, the more effectively and safely the body functions when functioning.

\section{Objectives}

1. To assess the pretest level of knowledge regarding hypnobirthing among women.

2. To assess the posttest level of knowledge regarding hypnobirthing among women.

3. To identify the association between level of knowledge regarding hypnobirthing among mother and selected demographic variables.

\section{MATERIAL AND METHODS}

The present study was a pre-experimental one group pre-test and post-test design which was conducted at antenatal clinic in AVBR Hospital, Wardha, Maharashtra, India. After approval (DMIMS(DU)/IEC/Sept-2019/8500 dated: 15.10.2019) from the institutional ethical committee and informed written consent of the Primigravida women.

\section{Inclusion Criteria:}

- Antenatal women who were willing to participate in the study.

- Antenatal women who were read, understand and speak English or Marathi.
- Antenatal women who were available at the time of data collection.

\section{Exclusion Criteria}

- Antenatal women who have attended and practicing hypnobirthing classes.: A tool or an instrument is the formal written document used to collect and record information. The tool for the present study was prepared by the investigators after extensive review of literature. A structure questionnaires consists of two sections. It is consisting of demographic characteristics regarding antenatal women's i.e. age, marital status, religion, residential area, education. It is consisting of 25 multiple choice questions to assess the knowledge regarding hypnobirthing among primigravida women. For the present study the validated tool was used structure questionnaire. The tool was in Marathi. Structure questionnaire contained 25 multiple choice questions. Data was collected within 15 days by group members pretest data collection was followed by structured teaching programme. Post test data collection with the same questionnaire was done 7 days after structured teaching programme. In order to obtain content validity, the tool was given to 7 experts from Department of obstetrics and gynaecology. It 0.858 split half method was used to establish internal consistency of the instrument and it was found to be 0.858 . Analysis was done in Descriptive statistic with mean, mean percentage and standard deviation and In inferential statistics with paired "t" test.

\begin{tabular}{|c|c|c|c|}
\hline \multirow[t]{2}{*}{ Level of Knowledge } & \multirow[t]{2}{*}{ Score Range } & \multicolumn{2}{|c|}{ Level of Knowledge Score } \\
\hline & & Pre score & Post score \\
\hline Poor & $1-5$ & $3(3 \%)$ & $0(0 \%)$ \\
\hline Average & $6-10$ & $61(61 \%)$ & $3(3 \%)$ \\
\hline Good & $11-15$ & $34(34 \%)$ & $7(7 \%)$ \\
\hline Very Good & $16-20$ & $2(2 \%)$ & $90(90 \%)$ \\
\hline \multicolumn{2}{|c|}{ Minimum Score } & 4 & 7 \\
\hline \multicolumn{2}{|c|}{ Maximum Score } & 16 & 20 \\
\hline \multicolumn{2}{|c|}{ Mean Knowledge Score } & $9.77(2.44)$ & $17.66(2.18)$ \\
\hline
\end{tabular}

Table 2. Evaluation of Planned Teaching on Knowledge Regarding Hypnobirthing Among Primigravida Women $n=100$

\begin{tabular}{|l|l|l|l|l|l|c|c|}
\hline Variable & Obs & Mean & Std. Dev. & \multicolumn{2}{|c|}{$\begin{array}{c}95 \% \text { Conf } \\
\text { Interval }\end{array}$} & t_Value & P_Value \\
\hline Pre_Score & 100 & $\begin{array}{c}9.77 \\
18.29\end{array}$ & $\begin{array}{c}2.44 \\
0.74\end{array}$ & $\begin{array}{c}9.28 \\
18.14\end{array}$ & $\begin{array}{l}10.25 \\
18.43\end{array}$ & 22.83 & 0.00 \\
Post_Score & 100 & & & \\
\hline
\end{tabular}

\section{RESULTS}

Section A- This section deals with percentage wise distribution of primigravida women. Percentage wise distribution of primigravida women acoording to their demographic characteristics.

- Distribution of primigravida women according to age in year 7\% of the primigravida women were in the 
age group of 18-20 years, 56\% in the age group of 21-25 years, 37\% in the age group 26-30 years .

- Distribution of primigravida women according to educational qualification. 8\% of the primigravida women were educated upto high school, 78\% upto HSC, 14\% upto graduation .

- Distribution of primigravida women according to Income. $10 \%$ of the primigravida women had income between $18000-20000$, 50\% of the primigravida women had income between 21000-25000, 23\% of the primigravida women had income between $26000-30000,11 \%$ of the primigravida women had income between 31000-35000.

- Distribution of primigravida women according to religion. \% of primigravida women were hindu, 1\% were muslim, 22\% were Buddhist.

- Distribution of primigravida women according to caste. $22 \%$ of primigravida women were belonging to SC, $8 \%$ of primigravida women were belonging to ST, 3\% of primigravida women were belonging to $\mathrm{VJ} / \mathrm{NT}$, 56\% of primigravida women were belonging to $\mathrm{OBC}, 2 \%$ of primigravida women were belonging to SBC, $9 \%$ of primigravida women were belonging to open.

- Distribution of primigravida women according to residenece. $76 \%$ of the primigravida women were belonging to rural area and $24 \%$ in urban areas respectively.

Section B: Assessment Of Knowledge Regarding Hypnobirthing Among Primigravida Women.

Section C: Evaluation of Planned Teaching On Knowledge Regarding Hypnobirthing Among Primigravida Women.

This table summarizes the comparison of pretest and post test scores for knowledge of primigravida women regarding hypnobirthing among primigravida women. In other terms, standard deviation and mean difference value Are equivalent and student's paired ' $t$ ' test applied at a sense point of 5 per cent. The value for $n$ tabled $=100-1$. The calculated 't' value i.e. 22.83 are much higher than the tabulated value at 5\% level of significance for overall knowledge score of primigravida women Is statistically reasonable significance point. Therefore it is interpreted statistically that the planned teaching programme on overall knowledge regarding hypnobirthing among primigravida women was effective. Thus the $\mathrm{H} 2$ is accepted.

\section{DISCUSSION}

A research on hypnobirthing antenatal childbirth care was performed at South Australia maternity unit. Antenatal hypnobirthing is associated with a decreased need for pharmacological therapies for childbirth4 Participants in the largest tertiary group 1 provide antenatal one center, guided trial using a 3-arm parallel group configuration hypnobirthing education in childbirth planning taught by a licensed therapist using a training in childbirth preparation provided by a trained therapist Using an audio-compact hypnobirth disk for enforcement; group 2 consists of an antenatal hypnobirth instruction in preparation for childbirth using an audio-compact hypnobirth disk provided by a nurse without training in hypnobirth therapy; group 3 participants begin their normal planning for childbirth with no further involvement. Hypnobirthing If Successful

A hypnobirthing-relaxation study. This has been used as a complement to the pharmacological treatment of 39 women hospitalized for premature contractions during pregnancy. Medication alone was misled by the control group and consisted of 70 people. Treatment started at the time of hospitalization and continued on average for 3 hours. Patients also got hypnobirthing cassettesrelaxation A research on hypnobirthing, hypnobirthing theoretical and practical knowledge among primigravida women. They asked a group of 100 primigravida women to complete a 20-question questionnaire. The results revealed that a significant degree of self-satisfaction among the groups in question primigravida women, most of the (90\%) women they give correct answer of score range is $16-20$ although only $7 \%$ of primigravida women they give correct answer score range is $11-15$ and 3\% women they give correct answer of score range 6-10 The results to present the analysis are described above. A number of studies in this region were reviewed which have direct or indirect effect on acquirement or progression of hypnosis among primigravida mothers.

\section{Implications To Nursing}

Nursing Practice: Nurses are the main tool for delivering health education, nurses will implement novel approaches for newly married couples, pre-pregnant mothers, pregnant women and others by discussing baby delivery wards under hypnosis there.

Nursing Education: Adequate monitoring and instruction are required for the advancement of student nurses by experienced teachers and staff nurses. Formal and informal teaching should be made available to nurses, so that patients can receive standardized nursing care.

Nursing Administration: Client's education services are an integral part of nursing care. The nursing administrator should see that the aspect of health promotion is included while providing care. Nurse administrators can plan for in- service and continuing nursing education regarding hypnobirthing.

Nursing Research: For the advancement of health teaching programs and family teaching programs, nurses researchers may also take the appropriate steps to incorporate the results of this report. Through conducting research, the nurse may contribute to the development of awareness about the efficacy of nursing action in alleviating its difficulties.

\section{Recommendation}

1. Similar study can be conducted by administering a planned teaching among hypnobirthing.

2. A similar study can be conducted on large population 
to generalize the findings.

3. A similar study can be conducted on assessment of knowledge and attitude and practice regarding hypnobirthing among primigravida women.

4. Similar study can be conducted in a different population.

\section{CONCLUSION}

In the present study a sample of 100 primigravida women were selected. A descriptive research design was adopted for the study with a view to measure the primigravida knowledge regarding hypnobirthing .The data was collected and analyzed statistically based on the objectives of the study.

\section{REFERENCES}

Agrawal, M., N. Acharya, K. Joshi, and D. Shrivastava. (2019) "Effectiveness of Isosorbide Mononitrate in Cervical Ripening before Induction of Labor in FullTerm Antenatal Patients." Journal of SAFOG 11, no. 2: 96-99. https://doi.org/10.5005/jp-journals-100061668

Barbara Harper, hypnobirthing basics, midwifery today magazine, summer 2000 .page no. 22-36.

C J Nehanegi, hypnobirthing for safe, less painful child delivery, merinews (2008) july11.

Kutti, Delivery babies underhypnosis, journal of obstetrics and gynecology (2000) page no. 333-336. Laxmansinghbhati, jouranal on nurses of india (2009) vol.10 Issue 11. Page no. 4-7.

Preparing for hypnobirthing, URI:http://www. hypnobirthing.htm

Sailypairmanjan pincombe et at, "textbook of midwifery preparation for practice' vol-4 page no. 431-432.

Selvanathan, S., N. Acharya, and S. Singhal. (2019) "Quality of Life after Hysterectomy and Uterus-Sparing Hysteroscopic Management of Abnormal Uterine Bleeding or Heavy Menstrual Bleeding." Journal of MidLife Health 10, no. 2 , 63-69. https://doi.org/10.4103/ jmh.JMH_15_19.

The bigsplash, URI://www.gulfmanorammaonline.com TriptiNath hypnobirthing in India gaining popularity, URI:http://www.oneworld.net

Widmer, M., G. Piaggio, T.M.H. Nguyen, A. Osoti, 0.0. Owa, S. Misra, A. Coomarasamy, et al. (2018) "Heat-Stable Carbetocin Versus Oxytocin to Prevent Hemorrhage after Vaginal Birth." Obstetrical and Gynecological Survey 73, no. 11: 613-14. https://doi. org/10.1097/0GX.0000000000000616 